\title{
NAZWY OBIEKTÓW NOCLEGOWYCH NA TERENIE GMINY BUKOWINA TATRZAŃSKA
}

Słow a tematy czne: infrastruktura turystyczna, chrematonimy, gmina Bukowina Tatrzańska

\section{WSTĘP}

Tatry i Podtatrze należą do miejsc chętnie odwiedzanych przez turystów już od dawna, lecz spektakularny rozwój turystyki na terenie gminy Bukowina Tatrzańska przypada na XXI wiek. Wioski, w których do niedawna głównym źródłem utrzymania były rolnictwo, hodowla owiec i bydła, z dnia na dzień stały się miejscowościami turystycznymi. W krajobrazie gminy wyrosły nowoczesne ośrodki narciarskie, kąpieliska termalne i bardzo duża liczba domów wczasowych, pensjonatów i kwater prywatnych. Procesowi temu towarzyszy nadawanie nazw nowym obiektom, które mają służyć turystom.

Obiekty turystyczne są wytworami człowieka, które powstały w wyniku zagospodarowania środowiska geograficznego i społecznego do celów turystycznych, motywowanych potrzebą wypoczynku, poznania i doznania przeżyć. Zaliczyć do nich można m.in.: obiekty noclegowe (hotele, pensjonaty, ośrodki), rekreacyjne (baseny, ośrodki narciarskie, kluby), gastronomiczne (karczmy, puby, restauracje) oraz różnego typu przedsięwzięcia kulturalne (skanseny, szlaki, festyny).

Nazwy obiektów turystycznych na terenie gminy Bukowina Tatrzańska nie były dotychczas przedmiotem analiz onomastycznych. Tematem niniejszego opracowania jest przedstawienie wyników wstępnych badań nad sposobami nazywania wybranej infrastruktury turystycznej powstałej w XXI w., czyli prześledzenie głównych tendencji w nazewnictwie nowo powstałych obiektów turystycznych oraz najczęściej wykorzystywanych mechanizmów nazwotwórczych. Ważne jest także zwrócenie uwagi na to, w jaki sposób wykorzystuje się tradycyjną kulturę i gwarę czy tzw. genius loci w kreowaniu miejsca atrakcyjnego dla turystów oraz jak nowe nazwy funkcjonują w lokalnej społeczności.

Materiał nazewniczy został pozyskany z szyldów, plakatów i folderów reklamowych obiektów turystycznych podczas własnych badań terenowych (wakacje 
2016 r.) oraz ze stron internetowych. W zbiorze tym znalazły się nazwy różnych obiektów turystycznych, m.in. noclegowych (domów wczasowych, pensjonatów, pokoi gościnnych, will), gastronomicznych (karczem, restauracji, kawiarni) i rekreacyjnych (ośrodków narciarskich, wyciągów, szkół narciarskich, basenów termalnych), ale w niniejszym artykule analiza dotyczy tylko obiektów noclegowych. Nazwy pozostałych obiektów będą opracowane osobno.

\section{ROZWÓJ TURYSTYKI W GMINIE}

Gmina Bukowina Tatrzańska położona jest na południu Małopolski, we wschodniej części powiatu tatrzańskiego. $\mathrm{Na}$ występowanie unikatowych walorów turystycznych tego regionu wpływ ma głównie położenie geograficzne. Górskie granie skalne stanowią $20 \%$ obszaru gminy, a około jedna trzecia powierzchni stanowi teren Tatrzańskiego Parku Narodowego, który objęty jest ochroną. Gminę Bukowina Tatrzańska tworzą części dwóch regionów etnograficznych: Podhala i Spisza. Do bukowiańskiej gminy należy osiem wsi: Białka Tatrzańska, Brzegi, Bukowina Tatrzańska, Czarna Góra, Groń, Jurgów, Leśnica i Rzepiska.

Specyfika regionu tatrzańskiego zaczęła się kształtować od początków osadnictwa, które z powodu górzystego, trudno dostępnego terenu nastąpiło stosunkowo późno. Początkowo powstawały sezonowe szałasy pasterskie, które z czasem przekształciły się w małe osady. Wioski na terenie gminy Bukowina Tatrzańska zostały założone na przełomie XVI i XVII w., chociaż wzmianki o poszczególnych osadach pojawiały się już wcześniej, m.in. w dokumentach mówiących o szałasach i owczarniach. Na powstanie charakterystycznego genius loci, czyli ducha miejsca, wpływ miały zasadniczo dwa czynniki: specyficzne środowisko naturalne oraz izolacja przestrzenna terenu, które sprzyjały wykształceniu się autentycznego góralskiego folkloru, wyrażającego się w zwyczajach, obrzędach, sztuce, muzyce, stroju i gwarze (por. Myga-Piątek 2011). Po okresie całkowitej izolacji Podtatrze zaczęło być odkrywane z końcem XIX w. przez przyjezdnych, których fascynowała oryginalna przyroda i kultura. Turyści przyjeżdżali głównie do Zakopanego, ale odbywając wędrówki do Morskiego Oka, pojawiali się także na terenie gminy Bukowina Tatrzańska. Ważnym wydarzeniem było wybudowanie drogi łączącej Bukowinę z Poroninem, a następnie uruchomienie linii autobusowej do Zakopanego w 1948 r., co znacznie przyczyniło się do rozwoju turystyki, zwłaszcza w samej Bukowinie Tatrzańskiej. Inne miejscowości gminy praktycznie nie były znane wśród turystów, którzy rzadko do nich docierali. Pierwsi letnicy lub (jak się mówi w lokalnej gwarze) kwartelnicy czy panowie przyjeżdżali zwykle na dłuższe pobyty w okresie letnim, wynajmując co roku u tych samych gazdów pokoje lub całe piętra domów. Pomimo wielu niedogodności spędzanie wakacji u gazdów cieszyło się dużym zainteresowaniem gości. Głównym powodem przyjazdów na wieś było przebywanie 
w naturalnym, nieskażonym zanieczyszczeniami środowisku i obcowanie z kulturą wiejską. Letnicy spędzali czas głównie nad rzeką Białką. Wędrówki do Morskiego Oka lub w inne miejsca Tatr były podejmowane rzadziej ze względu na dużą odległość i brak komunikacji.

Wybudowanie pierwszych wyciąów narciarskich w Bukowinie Tatrzańskiej pod koniec lat osiemdziesiątych minionego wieku spotkało się z dużym zainteresowaniem narciarzy. Prawdziwym przełomem dla gminy okazał się jednak początek XXI w. We wsi Białka Tatrzańska powstał nowoczesny kompleks narciarski Bania, który z roku na rok zwiększa i ulepsza swoją infrastrukturę, przyciagając tłumy miłośników białego szaleństwa. Po tej udanej inwestycji pojawiły się kolejne stacje narciarskie: Kotelnica i Kaniówka w Białce, Rusiński w Bukowinie, Koziniec i Grapa Litwinka w Czarnej Górze oraz Hawrań w Jurgowie. Obecnie na terenie gminy jest 15 kolei krzesełkowych i około 50 wyciagów orczykowych. Aby przyciągnąc turystów także poza sezonem zimowym, na terenie gminy wybudowano kąpieliska termalne: Termy Bukovina i Terma Białka, jedne z największych i najnowocześniejszych w Europie. Wraz z ośrodkami narciarskimi i kapieliskami rozwinęła się baza usługowa, w tym zwłaszcza noclegowa i gastronomiczna. W tej chwili w gminie znajduje się 20 tys. zarejestrowanych miejsc noclegowych (według danych Urzędu Gminy Bukowina Tatrzańska). Gmina Bukowina Tatrzańska stanowi obecnie ważny obszar recepcji różnych form turystyki w powiecie tatrzańskim (por. Komorowska 2003).

\section{NAZWY OBIEKTÓW TURYSTYCZNYCH — MATERIAŁ, WĄTPLIWOŚCI}

Obiekty turystyczne nie są równomiernie rozmieszczone na terenie całej gminy Bukowina Tatrzańska. Największe ich skupisko występuje w Białce i Bukowinie Tatrzańskiej. Zdecydowanie mniej obiektów jest w Jurgowie, Czarnej Górze oraz w pozostałych wsiach. Ich nazwy umieszczane są na szyldach budynków, plakatach reklamowych, bilbordach, ulotkach oraz na portalach reklamujacych turystykę. Moją bazę materiałową stanowi około 750 nazw obiektów noclegowych zebranych w czasie badań terenowych oraz pozyskanych ze stron internetowych i folderów reklamowych. Warto zwrócić uwagę, że nazwy pozyskane z szyldów oraz materiałów reklamowych różnią się zwykle od oficjalnych, podawanych np. w Panoramie firm. Są z reguły krótkie i nie zawierają pełnej informacji o podmiocie gospodarczym.

Nazwy mniejszych obiektów noclegowych są tworzone przez właścicieli lub osoby z ich środowiska. Nad wizerunkiem dużych obiektów pracują wyspecjalizowane agencje reklamowe. Na sposób nazywania obiektu ma wpływ wiele czynników językowych i pozajęzykowych, m.in. pragmatycznych, psycholingwistycznych, konotacyjnych i reklamowych (por. Biolik 2011; Dawidziak-Kładoczna 2010). 
Podczas gromadzenia materiałów zrodziło się kilka zasadniczych wątpliwości:

1. Do jakiej grupy onimów (chrematonimów czy mikrotoponimów) należy zaliczyć nazwy obiektów turystycznych (różne stanowiska w literaturze)?

2. Czy występujące na szyldzie samo określenie typu: Pokoje Gościnne, Pokoje, Pokoje do wynajęcia, Noclegi, Noclegi z wyżywieniem jest nazwą obiektu?

3. Czy nazwy zawierające określenia typu obiektu, np.: Chata u Bronka, Karcma u Dziubasów, Pokoje u Eli, stanowią w całości nazwę obiektu, czy tą nazwą jest tylko sam logonim (różne podejście w opracowaniach)?

4. Jak traktować nazwy mające na szyldach i materiałach reklamowych różnorodną grafię, np.: Jurgów SKI, Jurgów-SKI, Karcma u Dziubasów, Karcma , U Dziubasów", lub warianty, np.: U Górala, Dom u Górala, Domek u Górala?

Nazwy firm (usługowych, handlowych, produkcyjnych) stanowią intensywnie rozwijający się zbiór onimiczny od lat dziewięćdziesiątych ubiegłego wieku (por. Biolik 2011; Przybylska 1992), ale niektóre ich opracowania powstały jeszcze przed 1989 r., np. nazw domów wczasowych, will i pensjonatów (Bąba 1969; Kosyl 1981; Wajda 1973), karczem (Klisiewicz 1986) i lokali gastronomicznych (Breza 1988).

Wraz z pojawianiem się nowych firm wzrosło także zainteresowanie badaniami nazw tych obiektów. Omawiane są nazwy m.in.: aptek (Rutkiewicz 2000; Seiffert 2005), sklepów (Rzetelska-Feleszko 1994, 1998), pensjonatów (Gaczyńska-Piwowarska 2005), lokali gastronomicznych (Afeltowicz 2000; Biolik 2011), uczelni wyższych (Dacewicz 2007), biur matrymonialnych (Galasińska 1990), zakładów pogrzebowych (Parzniewska 1998), a także innych firm bez rozróżniania ich typu (Przybylska 1992; Kornaszewski 1994; Siwiec 2012). Klasyfikacja nazw firm jest w literaturze przedmiotu niejednolita. Częściej są one zaliczane do szeroko rozumianej chrematonimii, lecz niektórzy badacze rozpatrują nazwy aptek, lokali gastronomicznych, pensjonatów w ramach toponimii, biorąc za podstawę kryterium stałości związku obiektu z przestrzenią zamieszkaną przez ludzi (Breza 1998; Kosyl 1981). Wśród najnowszych publikacji uwagę zwraca studium Chrematonimy w funkcji kulturowo-użytkowej A. Gałkowskiego (2011), w którym autor, opierając się na szerokiej kulturowej definicji chrematonimii i formule użytkowości językowej, rozstrzyga wątpliwości dotyczące klasyfikacji tych obiektów. Chrematonimami użytkowymi badacz nazywa:

[...] wszystkie nazwy własne, będące niejako językowym dowodem ludzkiej aktywności w różnych obszarach kulturowych życia publicznego: przestrzeni społecznej, gospodarczej, kulturalnej, artystycznej, ludycznej, edukacyjnej, naukowej, technicznej, religijnej [...]. Przestrzenie te w każdym rozwiniętym kraju świata przepełnione są nazwami obiektów, organizacji, instytucji oraz przedsięwzięć, które sterują różnymi aspektami funkcjonowania człowieka w „nowoczesnej cywilizacji” (Gałkowski 2011: 51).

Nazwy obiektów turystycznych, np.: pensjonatów, ośrodków narciarskich, lokali gastronomicznych, mają bezpośredni związek z działalnością człowieka, czyli należą do chrematonimii użytkowej. 
Oficjalna nazwa firmy składa się zwykle z wieloskładnikowej struktury, np.: Przedsiębiorstwo Ustugowo-Gastronomiczne „Almi”, Restauracja „Zielony Gaj”, Zespót Pałacowo-Hotelowy Janusz Wrona. Integralną częścią niektórych chrematonimów jest krótka nazwa będąca symbolem firmy, np.: Almi, Eden, Orbis, Szwagropol. Element ten określany jest jako nazwa właściwa i zwany także firmonimem lub logonimem (Biolik 2011: 60; Przybylska 1992: 138; Siwiec 2012: 37-39). W opracowaniach nazw firmowych zwykle brane są pod uwagę nazwy właściwe, rzadziej omawiane są pełne nazwy przedsiębiorstw (Biolik 2011). Dla badaczy onimów istotnym problemem metodologicznym jest określenie tego, co jest rzeczywistą nazwą właściwą, a co grupą deskrypcyjną. Problem ten dotyczy także omawianych przeze mnie nazw obiektów turystycznych. Dyskusyjną sprawą jest to, czy określenie typu: Pokoje Gościnne lub Noclegi pełni funkcję nazwy właściwej obiektu, czy jest to apelatyw określający typ obiektu noclegowego. Niejednoznaczne są także nazwy typu: Chata u Bronka, Karcma u Dziubasów, Pokoje u Eli, w których wyrazy: chata, pokoje, karczma mogą być składnikami grupy deskrypcyjnej lub elementem nazwy własnej.

Jak wspomniałam we wstępie, założeniem artykułu jest omówienie sposobów nazywania noclegowej infrastruktury turystycznej, więc brane są pod uwagę wszystkie nazwy zarejestrowane w materiale. Uwzględnia się także konstrukcje z różnorodną grafią i odmiennymi sposobami nazywania tego samego obiektu, traktując je jako oryginalne nazwy.

\section{ELEMENTY NAZWY — MODELE STRUKTURALNE}

Nazwy obiektów turystycznych składają się najczęściej z kilku elementów: informacji o typie obiektu, nazwy właściwej obiektu, czyli logonimu, oraz niekiedy imienia i nazwiska właściciela. Sporadycznie występuje dodatkowa deskrypcja wskazująca na miejsce działalności lub podmiot działalności. W nazwach wieloskładnikowych poszczególne elementy występują zwykle w określonej kolejności: typ obiektu + nazwa właściwa + antroponim + (dodatkowa deskrypcja). Sporadycznie kolejność składników jest inna, np. nazwa właściwa + typ obiektu. Oprócz tego występują także struktury jednoskładnikowe, odwołujące się do typu obiektu lub będące nazwą właściwą.

Zebrane nazwy obiektów turystycznych pozwalają na wyodrębnienie kilku modeli strukturalnych, biorąc pod uwagę występowanie poszczególnych elementów.

Model 1: typ obiektu + logonim (ok. 400 nazw)

Obejmuje on grupę chrematonimów składającą się z dwóch składników: nazwy typu obiektu oraz nazwy właściwej. Typ obiektu określany jest jako: 
a) złożenie z członem agro-: agrotatry (skrót od agroturystyka w Tatrach), np.: Agrotatry u Stachy, Agrotatry za Lasem; agroturystyka, np.: Agroturystyka Grevanti, Agroturystyka u Czerników, Agroturystyka u Jędrusia;

b) apartament, np.: Apartament Babie Lato, Apartament u Julka, Apartamenty Gałajdówka, Apartamenty Rabiań-Ski; z dodatkowym rozszerzeniem rodzaju obiektu, np.: Apartamenty Willa Kaniówka, Apartamenty Domowe Ika, Apartamenty i Pokoje u Architekta;

c) bacówka, np.: Bacówka u Kazka, Bacówka u Malorza;

d) chata, chatka, np.: Chata pod Grapom, Chata u Brata, Chatka na Skalnym Brzyzku;

e) dom, domek, np.: Dom Danuta, Dom na Rusińskim 11, Dom przy Wyciagu, Dom u Pietrasa, Dom Wilkusowie, Domek Alpinka, Domki Bania; z dodatkowym rozszerzeniem rodzaju obiektu: Dom Janiny i Andrzeja Czerników Gracuś, Dom Pracy Twórczej i Wypoczynku Wojtuś, Dom Rekolekcyjny u Cystersów; z odwróconą kolejnością członów, np. Wiocha Domki do Wynajęcia; z dodatkowym określeniem: gościnny, np.: Dom Gościnny Franuś, Dom Gościnny Gawra; wczasowy, np.: Dom Wczasowy Burkatówka, Dom Wczasowy Wróbel; wypoczynkowy, np.: Dom Wypoczynkowy Anetka, Dom Wypoczynkowy Budzowie, Dom Wypoczynkowy Stasiki; z członami w odwróconej kolejności i dodatkowym rozszerzeniem, np. Zyg Zak Dom Wypoczynkowy i Centrum Turystyki;

f) dworek z dodatkowym określeniem, np.: Dworek Myśliwski Hubert, Słoneczny Dworek u Sarnów;

g) gościniec, np.: Gościniec Bartek, Gościniec na Wierchu, Gościniec nad Potokiem, Gościniec u Danusi, z dodatkowym rozszerzeniem, np. Gościniec i Herbaciarnia pod Złota Łyżwa;

h) hostel, np. Hostel Sabałówka;

i) hotel, np.: Hotel Carlina, Hotel Liptakówka, Hotel Zawrat Ski Resort \& Spa, Hotel Zbójnicówka;

j) kwatery, np.: Kwatery Dana, Kwatery Jaś $i$ Weronika; z dodatkowym rozszerzeniem: prywatne, np.: Kwatery Prywatne Beata, Kwatery Prywatne Chowańcówka, Kwatery Prywatne u Eli i Pawta;

k) noclegi, np.: Noclegi Babiarzowie, Noclegi Janik, Noclegi Sabałówka, Noclegi Stodoła, Noclegi u Dziubasów;

1) ośrodek, też z dodatkowym określeniem: wczasowy, np. Ośrodek Wczasowy Anna; wypoczynkowy, np.: Ośrodek Wypoczynkowy Groń-Placówka, Ośrodek Wypoczynkowy Watra;

ł) pensjonat, np.: Pensjonat Burkaty, Pensjonat Krywań, Pensjonat Mania, Pensjonat pod Końska Grzywa, Pensjonat Podhalanka, Pensjonat u Lusi, Pensjonat Zbójecki Dwór;

m) pokoje, np.: Pokoje Oliwka, Pokoje Siuster; z dodatkowym rozszerzeniem: wynajem pokoi, np.: Wynajem Pokoi 9 Sit, Wynajem Pokoi Danuta, Wynajem Pokoi 
Łasuch, Wynajem Pokoi u Krziscoka; z odwróconą kolejnością członów, np.: Janina. Wynajem Pokoi, Klon - Wynajem Pokoi; z dodatkowym określeniem: gościnne, np.: Pokoje Gościnne Eleni, Pokoje Gościnne pod Limba, Pokoje Gościnne Siedlisko, Pokoje Gościnne u Juhasa, Pokoje Gościnne u Pipisia, Pokoje Gościnne w Kotlinie; z odwróconą kolejnością, np.: Jaskier - Pokoje Gościnne, Jaśmin Pokoje Gościnne Bukowina, Skorusa - Pokoje Gościnne;

n) willa, np.: Willa Bukovina, Willa Maciejówka, Willa Magnat, Willa na Olczańskim Wierchu, Willa Pachówka, Willa Pan Tadeusz, Willa Parzenica, Willa Siuster Comfort, Willa Skatka;

o) wypoczynek, np.: Wypoczynek u Hajnosa, Wypoczynek u Kubusia, Wypoczynek u Moni;

p) zajazd, np.: Zajazd Pstrag, Zajazd u Milonów.

Sporadycznie występuje dodatkowa deskrypcja w postaci nazwy miejscowości lub imienia i nazwiska właściciela, np.: Dom Wypoczynkowy Dolinka Białka Tatrzańska, Dom Wypoczynkowy Morskie Oko - Bukowina Tatrzańska, Dom Wypoczynkowy Dawid - Anna i Ryszard Gut, Dom Wypoczynkowy Dolina Białki Halina i Mariusz Korkosz.

Model 2: typ obiektu + antroponim (ok. 80 nazw)

Model zawiera dwa składniki: nazwę typu obiektu oraz imię i nazwisko właściciela lub właścicieli. Na pierwszym miejscu jest zwykle nazwa typu obiektu, a na drugim antroponim, np.: Agroturystyka Stanisława Goryl, Dom Gościnny Katarzyna Bryjak, Dom Teresa i Stanistaw Para, Dom Wczasowy Maria i Jan Remiasz, Dom Wypoczynkowy Julia i Andrzej Budzowie, Noclegi - Zofia i Stanisław Niedzielski, Pokoje Helena i Andrzej Gasienica, Wynajem Pokoi - Anna i Adam Furczoń. Sporadycznie składniki występują w odwrotnej kolejności, np.: Łukaszczyk Janusz Wynajem Pokoi.

\section{Model 3: typ obiektu (60 nazw)}

Dość często na szyldach obiektów noclegowych zamieszczone są nazwy wskazujące tylko na typ obiektu, np.: Agroturystyka, Agroturystyka i apartamenty, Apartament, Apartament rodzinny, Apartamenty i pokoje gościnne, Dom rekolekcyjno-wypoczynkowy, Domek, Domek do wynajęcia i pokoje gościnne, Domek góralski, Domki do wynajęcia, Kwatery prywatne, Noclegi, Noclegi domek, Pokoje, Pokoje do wynajęcia, Pokoje gościnne, Pokoje gościnne z łazienkami, Pokoje gościnne z TV i łazienka, Pokoje gościnne z wyżywieniem, Pokoje z widokiem na Tatry, Tanie pokoje, Tanie spanie, Wolne pokoje, Wynajem pokoi, Willa. 
Model 4: typ obiektu + logonim + antroponim (ok. 30 nazw)

Model zawierający trzy składniki: nazwę typu obiektu, logonim oraz antroponim występuje głównie na ulotkach reklamowych i stronach internetowych, np.: Dom Wypoczynkowy Dawid - Anna i Ryszard Gut, Dom Wypoczynkowy Dolina Biatki Halina i Mariusz Korkosz, Pod Strzecha Wynajem Pokoi-Anna Nowobilska.

Model 5: antroponim (20 nazw)

Na szyldach obiektów noclegowych występują niekiedy tylko same imiona i nazwiska właścicieli, bez podania innych szczegółów dotyczących typu i nazwy obiektu, np.: Anna Fudala, Helena i Andrzej Chowaniec, Zofia i Józef Czernikowie.

Model 6: logonim (150 nazw)

Do tej grupy należą krótkie nazwy, które w większości nie zawierają informacji, że jest to obiekt noclegowy, np.: Ambrozja, Aśka, Bafia, Ceprówka, Gasienicówka, Góralski Zakatek, Podhalanka, Na Pukańcu, U Bajbusa. Określenia tego typu mogą określać dowolny obiekt z innej branży. Niektóre jednak nasuwają asocjacje dotyczące rodzaju obiektu, np.: Bukowa Chata, Góralska Chatka, Góralski Dworek, Spanko u Miśków, Villa 307 Spisz Resort.

Model 7: logonim + antroponim (10 nazw)

Sporadycznie w nazwach obiektów noclegowych występują dwa składniki: nazwa właściwa oraz imię i nazwisko właściciela, np.: Bukowianka - Anna Gał, Buńdówka - Anna i Jan Buńda, Dwa Światy Andrzej Pietras, Stasinda Zofia i Bronisław Rzadkosz, Tatrzańskie Widoki Zofia Babiarz.

\section{TYPY OBIEKTÓW}

Najczęściej występującymi określeniami typu obiektu w całym zbiorze nazw są apelatywy: pokoje gościnne (ok. 170), willa (ok. 70), wynajem pokoi (50), dom wypoczynkowy (45), apartamenty (30), noclegi (30), dom (20), pensjonat (20), agroturystyka (10), dom gościnny (10) oraz dom wczasowy (10). Rzadziej właściciele swoje obiekty określają jako: chata, chatka, bacówka, domek, gościniec, hotel, kwatery, kwatery prywatne, ośrodek wczasowy, ośrodek wypoczynkowy czy zajazd (po kilka poświadczeń). 


\section{LOGONIM}

W roli logonimów występują zarówno nazwy własne, jak i wyrazy pospolite. Popularnymi mianami pensjonatów są nazwy odantroponimiczne, utworzone od imion (często zdrobniałych), np.: Bartek, Basia, Dana, Franuś, Gabrysia, Jaś i Weronika, Jędruś, Maryna, lub nazwisk, przydomków właścicieli obiektów, np.: Babiarzowie, Dziubas, Janik, Siuster, Stasiki, Wilkusowie. Bardzo dużo nazw ma formę z przyimkiem $u$, np.: U Bronka, U Eli, U Chramca, U Gasienicy, U Leśnego, U Lusi, U Milonów, U Rusina. Dość często tworzone są formy z sufiksem -ówka od nazwisk lub przydomków właścicieli, np.: Chowańcówka, Gałajdówka, Sabałówka.

Charakterystyczną grupę tworzą nazwy od toponimów, będących określeniami górskich szczytów, np.: Czerwone Wierchy, Rysy, Hawrań, Krywań, Łomnica, jezior, np. Morskie Oko, miejscowości, np.: Brzegi, Bukovina, lub miejsc, np.: Dolina Białki, Kaniówka, Na Olczańskim Wierchu, Na Rusińskim, Rusiński, Podhalanka, Pod Kotelnica.

W nazwach obiektów często występują przymiotniki charakteryzujące przynależność do regionu, Tatr, miejscowości podtatrzańskich: białczański, bukowiański spiski, tatrzański, np.: Białczański Dworek, Bukowiańska Ostoja, Bukowiański Dworek, Dworek Spiski, Gościniec Tatrzański, Spiski Dworek czy Tatrzański Bartnik.

Wyrazy pospolite pełniące rolę logonimów należą do różnych klas wyrazów. Najczęściej są to: nazwy roślin — Limba, Magnolia, Pod Brzozami, Szarotka; miejsc: Nad Potokiem, Na Rozdrożu, Przy Kuźni, W Murowanicy; znane frazy: Babie Lato, Dwa Światy, Trzy Sroczki. Wyróżniającą się grupą są nazwy z przyimkiem pod, np.: Pod Ciupaga, Pod Końska Grzywa, Pod Limba, Pod Strzecha.

\section{KULTURA TATRZAŃSKA I GWARA PODHALAŃSKA}

W ofercie turystycznej często wykorzystuje się nazwy powszechnie znane, związane z regionem tatrzańskim, tzw. symbole regionu, np.: baca, ciupaga, gazda, harnaś, Morskie Oko, Łomnica, parzenica, watra, wierch. Określenia te występują także w nazewnictwie obiektów turystycznych. Wiele domów wypoczynkowych, willi i pokojów gościnnych nosi charakterystyczne dla tego obszaru nazwy typu: Gazda, Grań, Harnaś, Koliba, Łomnica, Morskie Oko, Parzenica, Pod Ciupaga, Szarotka, Turnia, U Juhasa, Watra, Wysoki Wierch.

Ważnym tworzywem wykorzystywanym w ofercie turystycznej jest mowa mieszkańców regionu Podtatrza. Po formy gwarowe sięgają właściciele pensjonatów, nadając swoim obiektom typowo lokalne miana, np.: Jedlo, Na Brzyzku, Na Grapie, Na Wierchu, Pod Grapom, Pod Smyrekami, Siumno, Skorusa, Smyrecek, Śleboda, 
lub zachowując w nazwach dialektalne cechy fonetyczne, np.: Biało Izba, Grześno Chata, Góralsko Izba, Pod Stancyjom, U Malorza, U Staska, Zbójnicko Grota ${ }^{1}$.

\section{ELEMENTY NOWE, ZAPOŻYCZONE}

Nowo powstające nazwy obiektów turystycznych często nawiązują do konstrukcji powszechnie stosowanych w branży turystycznej na świecie, wykorzystując całe angielskie określenia lub ich poszczególne elementy, np.: Aparthotel Delta Białka, Villa 307 Spisz Resort, Hotel Zawrat Ski Resort\&Spa, Pensjonat Silverton, Willa Highland. Stosuje się zabiegi zastępowania liter: $w$ przez $v$, np.: Hotel Bukovina, Villa Magnolia, Vanilia, Vera Pokoje Gościnne, $k$ przez c, np.: Hotel Carlina, Willa Siuster Comfort. Częstym elementem nowych nazw jest angielski rzeczownik ski (narty). Nazwy z członem ski mają różnorodną budowę - człon ten pisany jest łącznie z pierwszym członem, często poprzedzany łącznikiem, lub oddzielnie, zwykle wielką literą. Element ski występuje głównie w nazwach ośrodków narciarskich, wyciągów, szkół narciarskich, wypożyczalni, sklepów i serwisów narciarskich. Pojawiają się także nazwy noclegowe z tym leksemem, np.: Apartamenty RabiańSki,Thermal@Ski,Bania Ski. Rzadziej sięga się do innych języków, np. włoskiego, por.: Montenero, Willa Toscana, czy hiszpańskiego, np. Hacjenda.

\section{PODSUMOWANIE}

Nazwy obiektów turystycznych odgrywają dużą rolę w kreowaniu miejsca atrakcyjnego dla turystów. Na przykładzie gminy Bukowina Tatrzańska można obserwować proces glokalizacji, czyli połączenie globalnych działań z lokalnymi warunkami (oryginalną przyrodą i kultura). Właściciele, nadając swoim obiektom nazwy, sięgają do tego, co jest im najbliższe, co znają ze swojego otoczenia. Wiele określeń obiektów zostało przeniesionych z pierwotnych nazw toponimicznych występujących na terenie Tatr i Podtatrza. Często w nazewnictwie obiektów noclegowych wykorzystuje się także nazwy apelatywne z kultury i gwary podhalańskiej. Powszechnie znane nazwy górskich szczytów, miejsc oraz wytworów kultury materialnej i niematerialnej funkcjonują w nowym znaczeniu, otrzymując „,nowe życie". Można zatem stwierdzić, że głównym sposobem tworzenia nazw obiektów noclegowych są neosemantyzmy. Bazowanie na elementach tradycyjnej kultury w nazewnictwie ma wpływ na powstawanie nowego genius loci. Warto zwrócić

\footnotetext{
${ }^{1}$ Znacznie wyrazów gwarowych: brzyzek 'strome wzniesienie', grapa 'strome wzniesienie', jedlo 'jodła', siumny 'elegancki, urodziwy', skorusa 'jarzębina', śleboda 'wolność', smyrek 'świerk', wierch 'pagórek, góra'.
} 
uwagę, że nazwy w nowym kontekście występują nie tylko w kodzie turystów, ale również lokalnej społeczności, np.: sqsiadka pracuje $w$ Harnasiu, robiliśmy z kumplem na Bani przez cała zimę, sprzatam w Morskim Oku. Nazwy obiektów tworzone są także od antroponimów: imion, nazwisk i przydomków właścicieli. Popularną grupą nazw odantroponimicznych obiektów noclegowych są określenia z przyimkiem $u$, np.: U Marysi, U Kuruca. W nazywaniu obiektów noclegowych obserwuje się tendencję do tego, aby każdy obiekt miał swoją niepowtarzalną nazwę własną. Na 750 nazw obiektów wystąpiło prawie 600 konstrukcji zawierających logonimy.

\section{LITERATURA}

Afeltowicz B. 2000: Nazwy lokali gastronomicznych w Szczecinie, [w:] M. Czachorowska, Ł. M. Szewczyk (red.), Onomastyka polska a nowe kierunki językoznawcze. Zbiór artykułów naukowych, WSP, Bydgoszcz, s. 195-210.

Bąba S. 1969: O imionach domów wczasowych, „Pomorze” 15, nr 9, s. 14.

Biolik M. 2011: Modele strukturalne nazw własnych przedsiębiorstw i lokali branży gastronomicznej w województwie warmińsko-mazurskim, [w:] M. Biolik, J. Duma (red.), Chrematonimia jako fenomen wspótczesności, UWM, Olsztyn, s. 59-78.

Breza E. 1988: Nazwy lokali gastronomicznych w obecnym województwie gdańskim, „Zeszyty Naukowe Uniwersytetu Gdańskiego. Prace Językoznawcze” 14, s. 115-123.

Breza E. 1998: Nazwy obiektów i instytucji zwiqzanych z nowoczesnq cywilizacja (chrematonimy), [w:] E. Rzetelska-Feleszko (red.), Polskie nazwy własne. Encyklopedia, IJP PAN, Warszawa-Kraków, s. 334-361.

Dacewicz L. 2007: Nazwy polskich uczelni wyższych — tradycja i współczesność, [w]: A. Cieślikowa, B. Czopek-Kopciuch, K. Skowronek (red.), Nowe nazwy własne - nowe tendencje badawcze, Pandit, Kraków, s. 521-528.

Dawidziak-Kładoczna M. 2010: Chata tylko dla ciebie, czyli o strategiach reklamowych w nazwach obiektów noclegowych, [w:] R. Łobodzińska (red.), Nazwy własne a społeczeństwo, t. 2, Leksem, Łask, s. 311-322.

Gaczyńska-Piwowarska H. 2005: Nazwy pensjonatów i domów wczasowych w Karkonoszach, [w:] R. Łobodzińska (red.), Z najnowszych tendencji w polskim nazewnictwie, Oficyna Wydawnicza Leksem, Łask, s. 99-107.

Galasińska A. 1990: Nazwy biur matrymonialnych, „Onomastica” XXXV, s. 103-112.

Gałkowski A. 2011: Chrematonimy w funkcji kulturowo-użytkowej, Wyd. UŁ, Łódź.

Klisiewicz E. 1986: Nazwy karczem w Tarnopolszczyźnie, „Rocznik Naukowo-Dydaktyczny WSP w Krakowie 104. Prace Językoznawcze" 5, s. 177-187.

Komorowska K. 2003: Turystyka a społeczności lokalne — przykład tatrzański, „Studia Regionalne i Lokalne" 3 (13), s. 79-89.

Kornaszewski M. 1994: Hybrydalne nazwy poznańskich przedsiębiorstw, „Poznańskie Studia Polonistyczne. Seria Językoznawcza" 1/21, s. 85-91.

Kosyl C. 1981: Z problematyki nazw will, pensjonatów i domów wczasowych, „Onomastica” XXVI, s. $103-118$.

Myga-Piątek U. 2011: Genius loci Podhala i Tatr. Rola w ksztattowaniu atrakcyjności turystycznej, „Prace Komisji Krajobrazu Kulturowego” 15, s. 259-278. 
Parzniewska J. 1998: Nazwy zakładów pogrzebowych, „Onomastica” XLIII, s. 283-289.

Przybylska R. 1992: O wspótczesnych nazwach firm, „Język Polski” LXXII, s. 138-150.

Rutkiewicz M. 2000: Semantyka nazw poznańskich aptek, „Język Polski” LXXIX, s. 185-196.

Rzetelska-Feleszko E. 1994: Najnowsze nazwy sklepów, [w:] E. Wrocławska (red.), Uwarunkowania i przyczyny zmian językowych, „Język na Pograniczach” 11, Warszawa, s. 133-142.

Rzetelska-Feleszko E. 1998: Obecne nazwy firmowe w Polsce $i$ w Europie, „Onomastica” XLIII, s. 267-281.

Seiffert I. 2005: Nazwy wrocławskich aptek — przeszłość i wspótczesność, [w:] R. Łobodzińska (red.), Z najnowszych tendencji w polskim nazewnictwie, Leksem, Łask, s. 83-98.

Siwiec A. 2012: Nazwy własne obiektów handlowo-uslugowych w przestrzeni miasta, Wyd. UMCS, Lublin.

Wajda L. 1973: Nazwy will w Zakopanem, „Rocznik Naukowo-Dydaktyczny WSP w Krakowie. Prace Językoznawcze" 2, s. 179-189.

Bukowina Tatrzańska - serwis informacyjny i noclegowy, http://www.bukowinatatrzanska.pl/ (dostęp 8 IX 2016).

Czas na Biatkę, http://www.czasnabialke.pl/ (dostęp 8 IX 2016).

Noclegi - kwatery, hotele, pensjonaty, apartamenty, http://www.nocowanie.pl/ (dostęp 20 IX 2016).

Noclegi - tanie noclegi nad morzem, w górach, https://e-turysta.net/ (dostęp 20 IX 2016).

Tatry-SKI, http://tatryski.pl/ (dostęp 8 VI 2015).

Urzad Gminy Bukowina Tatrzańska, http://ugbukowinatatrzanska.pl/index.php (dostęp 8 VI 2015).

\section{THE NAMES OF ACCOMMODATION FACILITIES IN BUKOWINA TATRZAŃSKA COMMUNE}

\section{SUMMARY}

The article describes ways of naming of the tourist infrastructure created in the 21 st century in the Tatra commune. The material base consists of 750 names of an accommodation facilities collected during personal research in Bukowina Tatrzańska commune. The names were obtained also from internet websites and brochures of tourist facilities.

The collected names are to be divided into several structural models. Typically names of accommodation facilities consist of two elements: type of object + proper name. The names of accommodation facilities are usually influenced by the culture and dialect of the Tatra region.

Ke y w ord s: tourist infrastructure, chrematonyms, Bukowina Tatrzańska commune 